\title{
Modal Sosial: Konsep, Inklusivitas dan Pemberdayaan Masyarakat ${ }^{1}$
}

\author{
Rusydan Fathy²
}

\begin{abstract}
Abstraksi
Modal sosial diasumsikan sebagai alternatif bentuk modalitas lain. Secara teoritis ada perdebatan mengenai modal sosial bermuara kepada relasi-relasi sosial. Perdebatan itu berkenaan dengan konseptualisasi modal sosial sebagai kapital konkrit dimana individu atau kelompok mampu mendayagunakan relasi-relasi sosial mencakup nilai-norma, jaringan sosial dan kepercayaan untuk memperoleh keuntungan ekonomi dan manfaat sosial. Menggunakan pendekatan kualitatif dengan metode studi literatur, artikel ini bertujuan untuk menjelaskan modal sosial sebagai konsep teoritis. Pemaparan studi menunjukkan adanya hubungan antara modal sosial dengan inklusivitas dan pemberdayaan masyarakat terutama dalam konteks pembangunan inklusif berkelanjutan. Artikel ini menyimpulkan bahwa konsep modal sosial berfungsi sebagai kerangka berpikir yang bermanfaat dalam keberhasilan pembangunan dan perumusan kebijakan.
\end{abstract}

Kata kunci: konsep teoritis, social capital, relasi sosial, pembangunan inklusif berkelanjutan.

\begin{abstract}
Social capital assumed as an alternative form of other modalities. Theoritically, the debate on social capital ended up to social relations. The debate concerns a conceptualization of social capital as concrete capital wherein individuals or communities are able to utilize social relations including values - norms, social networks and trust in order to gain economic and social benefits. Using qualitative method of literature study, this article aims to provide a further explanation on social capital as theoritical concept. The explanatory study shows that social capital interconnects with inclusiveness and community empowerment especially on the context of sustainable inclusive development. This article concludes that the concept of social capital is functioned as a useful theoretical framework for accomplished development and policy formulation.
\end{abstract}

Keywords: theoretical concept, social capital, social relations, sustainable inclusive development,

\section{A. Pendahuluan}

Pada hakikatnya pembangunan bertujuan untuk mencapai kesejahteraan. Namun demikian, implementasi pembangunan nasional yang terangkum dalam agenda pemerintah baik pusat maupun daerah masih dirasa kurang efektif dalam mencapai cita-cita tersebut. Bagi Indonesia, salah satu tujuan nasional adalah mencerdaskan kehidupan bangsa dan meningkatkan kesejahteraan umum. Namun, nampaknya hal itu sulit dicapai melihat fakta masih banyak masyarakat yang tereksklusi sosial. Sila ke 5 Pancasila yaitu Keadilan
Sosial bagi Seluruh Rakyat Indonesia menjadi berseberangan dengan fakta kesenjangan yang tetap tajam antara si kaya dan si miskin. Tingkat pendidikan yang rendah dan tidak merata, infrastruktur yang terbatas di pedalaman, kualitas sanitasi dan kesehatan yang buruk serta lemahnya partisipasi masyarakat dalam aktifitas politik menjadi bukti melemahnya kapasitas masyarakat akibat agenda pembangunan yang tidak inklusif.

Padahal, kita sedang dihadapkan oleh agenda global Sustainable Development Goals (SDGs) menggantikan Millenium Development

\footnotetext{
${ }^{1}$ Untuk kutipan atau sitasi artikel ini: Fathy, Rusydan. 2019. "Modal Sosial: Konsep Inklusivitas dan Pemberdayaan Masyarakat." Jurnal Pemikiran Sosiologi Vol.6 (1): 1-17

2 Pusat Penelitian Kemasyarakatan dan Kebudayaan - Lembaga Ilmu Pengetahuan Indonesia. Kontak penulis: rusydanfathy@gmail.com
} 
Jurnal Pemikiran Sosiologi Volume 6 No.1 2019

Modal Sosial: Konsep, Inklusivitas dan Pemberdayaan Masyarakat

Rusydan Fathy

Goals. SDGs merupakan upaya negera-negara di dunia untuk menciptakanBumi sebagai tempat yang lebih baik bagi manusia. Tujuan tersebut terangkum dalam 17 tujuan yang merefleksikan inklusivitas dan sustainability. Agenda tersebut mengharuskan perumusan dan implementasi kebijakan yang merangkul semua dan bersifat berkelanjutan (memperhatikan kelangsungan hidup generasi berikutnya).

Di sisi lain, konsep modal sosial menarik perhatian para akademisi dan praktisi di dalam isu pembangunan. Modal sosial kemudian dianggap sebagai kerangka teoritis yang bermanfaat dalam paradigma pembangunan inklusif berkelanjutan. Posisi modal sosial menjadi penting untuk disorot mengingat paradigma pembangunan yang diberlakukan tersebut lebih bersifat bottom up ketimbang top down. Modal sosial masuk dalam dimensi sosial dari paradigma pembangunan berkelanjutan yang mencoba mengintegrasikan tiga dimensi: sosial, ekonomi dan lingkungan. Selain itu, posisi modal sosial juga berperan positif dalam dimensi politik karena mendorong partisipasi, aksesibilitas dan kebebasan masyarakat yang juga menjadi prinsip dalam paradigma pembangunan inklusif berkelanjutan.

\section{B. Metode dan Kerangka Konseptual: Relasi dan Proses dalam Modal Sosial}

Secara metodologis, penelitian ini menggunakan pendekatan kualitatif dengan menggunakan kajian literatur dalam membahas kerangka konseptual tentang modal sosial. Dilihat dari segi sumber daya yang terendap di dalamnya, modal dapat dikategorikan menjadi beberapa bentuk: modal finansial, modal fisik, modal manusia dan modal sosial. Masing-masing bentuk modal tersebut memiliki perbedaan dalam pola atau proses investasi untuk memperoleh keuntungan ekonomi (economic gain) dan manfaat sosial (social benefit) (Usman, 2008: 1)

Modal sosial saat ini banyak dipakai oleh para akademisi maupun praktisi dalam berbagai kajian. Modal sosial terutama hadir sebagai alternatif bentuk modalitas lain seperti modal ekonomi, modal budaya dan modal manusia. Pierre Bourdieu (1986) memperkenalkan konsep modal sosial dalam konteks perdebatan bentuk-bentuk modalitas tersebut. Bourdieu memperdebatkannya dengan melihat peluangnya untuk dikonversikan. Menurut Bourdieu, bukan hanya modal ekonomi yang mudah dikonversikan ke dalam bentuk uang, melainkan modal budaya yang pada situasi tertentu, dapat dikonversikan menjadi modal yang memiliki nilai ekonomi. Usman menjelaskan (2018):

Modal ekonomi atau finansial dihubungkan dengan upaya mengelola, meingkatkan, mengalokasikan dan menggunakan dana yang dimiliki sebagai sumber daya moneter untuk memperoleh keuntungan ekonomi atau manfaat sosial melalui kegiatan produktif. Modal fisik lebih dihubungkan kepada faktor produksi barang atau jasa yang dalam konteks ini adalah bahan baku serta infrastruktur untuk mengolahnya. Modal manusia lazim dikaitkan dengan upaya mendayagunakan kepandaian, keterampilan (skill), tingkat dan keragaman pendidikan serta pengalaman individual. Modal sosial memfokuskan pada upaya mendayagunakan relasi-relasi sosial. (Usman, 2018: 3-4). 
Jurnal Pemikiran Sosiologi Volume 6 No.1 2019

Modal Sosial: Konsep, Inklusivitas dan Pemberdayaan Masyarakat

Rusydan Fathy

Sejak saat itu, perdebatan tentang apakah modal sosial memenuhi syarat sebagai modal terus berlanjut. Sementara beberapa penulis berpendapat bahwa modal sosial tidak menjunjung tinggi properti utama teori modal klasik dan, karenanya, tidak memenuhi syarat sebagai modal, yang lain mempertahankan bahwa sebagian besar sifat modal sosial mirip dengan teori modal klasik. Pengetahuan tentang teori modal klasik adalah prasyarat untuk berkontribusi pada perdebatan modal sosial (Bhandari dan Ysinoubu, 2009). Namun demikian, ada keyakinan bahwa modal sosial menyorot relasi atau hubungan sosial sedangkan bentuk-bentuk lain dari modal terutama terletak pada individu saja (Robison et al, 2002 dalam Bhandari dan Ysinoubu, 2009).

Konsep modal sosial sebenarnya muncul dari pemikiran bahwa anggota masyarakat tidak mungkin dapat secara individu mengatasi berbagai masalah yang dihadapi. Diperlukan adanya kebersamaan dan kerjasama yang baik dari segenap anggota masyarakat yang berkepentingan untuk mengatasi hal tersebut (Syahra, 2003). Syahra (2003) mengemukakan:

Pemikiran seperti inilah yang pada awal abad ke 20 mengilhami seorang pendidik di Amerika Serikat bernama Lyda Judson Hanifan untuk memperkenalkan konsep modal sosial pertama kalinya. Dalam tulisannya berjudul 'The Rural School Community Centre' (Hanifan, 1916:130). Hanifan mengatakan modal sosial bukanlah modal dalam arti biasa seperti harta kekayaan atau uang, tetapi lebih mengandung arti kiasan, namun merupakan aset atau modal nyata yang penting dalam hidup bermasyarakat. Menurut Hanifan, dalam modal sosial termasuk kemauan baik, rasa bersahabat, saling simpati, serta hubungan sosial dan kerjasama yang erat antara individu dan keluarga yang membentuk suatu kelompok sosial. (ibid: 2).

Modal sosial bukan semata-mata dilihat sebagai sebuah hasil melainkan lebih kepada proses. Modal sosial mengalami pembentukan terus-menerus dan senantiasa mengakumulasi dirinya. Berbeda dengan bentuk modalitas lain, modal sosial tidak akan pernah habis ketika dipakai. Kualitas modal sosial justru akan semakin baik apabila sering dimanfaatkan. Berkenaan dengan hal tersebut, beberapa faktor umum yang mempengaruhi pembentukan modal adalah: kebiasaan, kedudukan (peranan aktor), pendidikan, kelas sosial ekonomi dan nilai-nilai personal. Modal sosial terutama berakar pada gagasan kepercayaan, norma, dan jaringan informal dan percaya bahwa relasi sosial adalah sumber daya yang berharga (Bhandari dan Yasinoubu, 2009). Ketiga hal tersebut, yaitu norma sosial, jaringan sosial dan kepercayaan merupakan indikator atau unsur modal sosial. Ketiganya merupakan hubungan saling berkelindan.

Pada prinsipnya, modal sosial berbicara mengenai ikatan atau kohesi sosial. Gagasan sentral modal sosial tentang ikatan sosial adalah bahwa jaringan merupakan aset yang sangat bernilai dasar bagi kohesi sosial karena mendorong iklim kerjasama untuk memperoleh manfaat (Field, 2010). Pada kenyataannya, menggunakan hubungan untuk bekerjasama membantu orang memperbaiki kehidupan mereka (Putnam, 2000: 19 dan Woolcock, 1998 dalam Field, 2010). Relasi-relasi sosial tersebut dapat diberdayakan sebagai modal untuk mendapat bukan hanya keuntungan ekonomi tetapi juga manfaat sosial (Usman, 2018). 
Jurnal Pemikiran Sosiologi Volume 6 No.1 2019

Modal Sosial: Konsep, Inklusivitas dan Pemberdayaan Masyarakat

Rusydan Fathy

Pertanyaannya kemudian, seperti yang diajukan oleh Usman (2018) adalah bagaimana orang mendayagunakan relasi-relasi sosial sehingga menjadi sumber daya yang dapat dinvestasikan untuk tujuan memperoleh keuntungan ekonomi atau manfaat sosial? Untuk dapat menjawab pertanyaan tersebut adalah dengan menelisik efek atau dampak dari relasi-relasi sosial.

Pertama, relasi sosial memfasilitasi aliran informasi tentang berbagai macam kebutuhan lingkungan. Penguasaan informasi memiliki peran penting dalam memprediksi kebutuhan yang tumbuh dan berkembang dalam masyarakat. Kedua, relasi sosial berkorelasi positif dengan pengaruh yang mampu menjadi kekuatan memobilisasi dukungan. Ketiga, relasi sosial adalah media menanamkan dan menebarkan trust sehingga orang dapat mengembangkan hubungan yang saling menguntungkan satu-sama lain. Keempat, relasi sosial adalah media mempertegas identitas sehingga orang mudah mengembangkan hubungan yang saling menghargai. Hubungan saling menghargai tersbeut menciptakan kondisi kondusif untuk berbagi kepentingan dan sumber daya. Hubungan semacam ini bukan hanya memberikan rasa aman tetapi juga memberi jaminan keberlangsungan kegiatan (Koput, 2010: 4-6 dalam Usman, 2018: 5).

\section{Mendefinisikan Modal Sosial: Norma, Jaringan dan Kepercayaan sebagai Elemen Inti}

Istilah modal sosial sejatinya merujuk kepada kapasitas individu untuk memperoleh barang material atau simbolik yang bernilai berdasarkan kebajikan hubungan sosial dan keanggotaan dalam kelompok sosial atau kapasitas pluralitas seseorang untuk menikmati keuntungan dari tindakan kolektif berdasarkan kebajikan dari partisipasi sosial, kepercayan terhadap institusi atau komitmen untuk menetapkan cara dalam melakukan sesuatu (Ritzer, 2004).

Menurut Portes (1998) modal sosial adalah kemampuan dari para aktor untuk menjamin manfaat dengan bertumpu pada keanggotaan dalam jejaring sosial dan struktur-struktur sosial lain. Sedangkan menurut Woolcock (1998) modal sosial adalah derajat kohesi sosial yang ada dalam komunitas. Ia mengacu pada proses-proses antar orang yang membangun jejaring, norma-norma, dan social trust, dan memperlancar koordinasi dan kerjasama yang saling menguntungkan. Kemudian Lang \& Hornburg (1998) berpendapat bahwa modal sosial umumnya merujuk pada ketersediaan rasa saling percaya di dalam masyarakat (stocks of sosial trust), norma-norma, dan jejaring yang dapat dimanfaatkan masyarakat dalam rangka menyelesaikan persoalan-persoalan bersama.

Coleman (1989) melihat modal sosial sebagai keseluruhan sesuatu yang diarahkan atau diciptakan untuk memudahkan tindakan individu dalam struktur sosialnya. Sementara itu Putnam mengatakan, sedangkan modal fisik mengacu kepada objek-objek fisik dan modal manusia mengacu kepada properti individu, modal sosial merujuk kepada hubungan antara individu, jaringan sosial dan norma-norma timbal balik serta kepercayaan yang timbul dari mereka (2000: 19). Baik Coleman dan Putnam sama-sama mengakui bahwa modal sosial dapat bertambah maupun berkurang dari waktu ke waktu (Field, 2010). Sama 


\section{Jurnal Pemikiran Sosiologi Volume 6 No.1 2019 \\ Modal Sosial: Konsep, Inklusivitas dan Pemberdayaan Masyarakat \\ Rusydan Fathy}

halnya Coleman dan Putnam, Fukuyama (2002) menjelaskan bahwa setiap kelompok memiliki potensi modal sosial - sejauh mana ia dimanfaatkan berkenaan dengan radius kepercayaan. Keragaman analisis konsep modal sosial dari beberapa tokoh dapat dipetakan sebagai berikut:

\section{Konsep Teoris (Tokoh yang mengajukan teori/konsep) dan Analisis \\ Aset Menurut Bourdieu, Coleman, Putnam, modal sosial adalah aset individual aktor, kemudian berkembang menjadi aset kelompok. \\ Menurut Fukuyama, modal sosial adalah aset kelompok yang dimanfaatkan oleh individu aktor \\ Kedekatan Menurut Bourdieu, Coleman dan Putnam, kedekatan hubungan sangat vital dalam Hubungan mengidentifikasi modal sosial. Kedekatan hubungan melembagakan trust norma dan hubungan saling menguntungkan. Mereka berfokus kepada bonding social capital, \\ Menurut Fukuyama, kedekatan hubungan tidak terlaalu dominan karena bisa dihubungkan oleh aktor-aktor tertentu (sebagai jembatan sekaligus pengarah) dan selanjutnnya melembagakan linking social capital. \\ Fungsi Menurut Bourdieu, Coleman, Putnam, modal sosial berfungsi sebagai agen perubahan sosial dan dapat memberi dukungan individual aktor atau kelompok mencapai berbagaa tujuan dan memenuhi kepentingan.}

Tabel 1: Pemetaan Modal Sosial (Sumber: Usman, 2018)

Haridison (2013) berkesimpulan bahwa pandangan beberapa ahli tentang konsepsi modal sosial adalah: (1) sekumpulan sumberdaya aktual dan potensial; (2) entitasnya terdiri-dari atas beberapa aspek dari struktur sosial, dan entitasentitas tersebut memfasilitasi tindakan individu-individu yang ada dalam struktur tersebut; (3) asosiasi-asosiasi yang bersifat horisontal; (3) kemampuan aktor untuk menjamin manfaat; (4) informasi; (5) norma-norma; (6) nilai-nilai; (7) resiprositas; (8) kerjasama; (9) jejaring. Sementara itu Coleman (2011) berpendapat bahwa terdapat 6 bentuk modal sosial: kewajiban dan ekspektasi, saluran informasi, norma dan sanksi efektif, relasi wewenang, organisasi sosial yang disesuaikan, organisasi yang disengaja.

Terkait hal tersebut, Haridison (2013:35) menjelaskannya dalam enam aspek. Pertama, Kewajiban dan Ekspektasi. Jika A melakukan sesuatu untuk B dan percaya bahwa B akan membalasnya pada masa depan, hal ini menciptakan ekspektasi di pihak A dan kewajiban di pihak B untuk memelihara kewajiban tersebut. Kedua, Saluran Informasi. Potensi informasi yang melekat pada relasi-relasi sosial. Informasi penting untuk mendasari tindakan, tetapi akuisisi informasi merugikan. Informasi sekurang-kurangnya memerlukan perhatian, yang selalu cepat diberikan. Alat yang dapat digunakan untuk mendapatkan informasi adalah penggunaan relasi sosial yang dipertahankan untuk tujuan lain. Ketiga, Norma dan Sanksi Efektif. Norma-norma preskriptif yang merupakan bentuk modal sosial sangat penting dalam kolektivitas adalah norma yang membuat seseorang melepaskan kepentingan diri sendiri untuk bertindak demi kepentingan kolektivitas. Keempat, Relasi Wewenang. Jika pelaku A mengalihkan hak kendali beberapa tindakan kepada pelaku lain, B, maka B menyediakan modal sosial dalam bentuk hak kendali tersebut. Kelima, Organisasi Sosial yang Dapat Disesuaikan. Organisasi yang didirikan untuk satu rangkaian tujuan juga dapat membantu tujuan lainnya. Keenam. Organisasi yang Disengaja. Penggunaan konsep modal sosial tergantung pada keberadaan 


\section{Jurnal Pemikiran Sosiologi Volume 6 No.1 2019 \\ Modal Sosial: Konsep, Inklusivitas dan Pemberdayaan Masyarakat \\ Rusydan Fathy}

hasil sampingan aktivitas yang diikutsertakan untuk tujuan lain.

Di sisi lain, modal sosial memiliki dua dimensi yaitu dimensi kognitif (kultural) dan dimensi struktural (Bain dan Hicks dikutip Krishna dan Shradder dalam Syahra, 2003). Dimensi kognitif berkaitan dengan nilai-nilai, sikap dan keyakinan yang mempengaruhi kepercayaan, solidaritas dan resiprositas yang mendorong ke arah terciptanya kerjasama dalam masyarakat guna mencapai tujuan bersama. Dimensi struktural merupakan susunan, ruang lingkup organisasi dan lembaga-lembaga masyarakat pada tingkat lokal yang mewadahi dan mendorong terjadinya kegiatan-kegiatan kolektif yang bermanfaat bagi masyarakat.

Pemaparan mengenai definisi, perdebatan, dimensi dan bentuk modal sosial mengantarkan kita kepada kesimpulan bahwa pada dasarnya modal sosial memiliki tiga unsur penting yaitu nilai norma, jaringan dan kepercayaan. Unsur yang pertama yaitu norma-norma sosial (social norms). Secara umum norma merupakan nilai yang bersifat kongkret. Diciptakan untuk menjadi panduan bagi setiap individu untuk berperilaku sesuai dengan aturan yang berlaku di masyarakat. Terkait hal ini, Putnam (2000) menjelaskan bahwa nilai-nilai terkandung di dalam suatu jaringan sosial. Dengan demikian dapat dikatakan bahwa posisi nilai-nilai menjadi penting sebagai pengikat atau perekat kohesivitas - mempersatukan dalam menjalin hubungan. Menurut Fukuyama:

Pada umumnya norma yang terbentuk secara spontan cenderung bersifat informal, dalam arti tidak dituliskan dan diumumkan.
Selain merentangkan norma-norma sosial, mulai dari norma sosial hierarkis hingga norma spontan, kita juga dapat merentangkan norma lainnya hasil pilihan rasional, serta norma turun menurun dan arasional. (Fukuyama, 2005: 179).

Fukuyama (2005) menjelaskan lebih lanjut, bahwa akan terbentuk 4 macam norma dengan 4 sifat yang berbeda: spontan-arasional (alami teratur sendiri), spontan rasional (tertata sukarela), hierarkis-arasional (keagamaan) dan hierarkisrasional (politis). Nilai dan norma merupakan pra kondisi - pondasi yang melandasi timbulnya kepercayaan (Fukuyama, 2002). Norma-norma informa ini tidak akan lenyap dan akan tetap di kemudian hari (Fukuyama, 2005: 230). Normanorma ini pada gilirannya akan menciptakan kebajikan sosial (Social Virtues):

Beberapa rangkaian kebajikan individu yang bersifat sosial di antaranya adalah kejujuran, keterandalan, kesediaan untuk bekerja sama dengan orang lain, kekompakkan dan sense of duty terhadap orang lain... Modal sosial memerlukan pembiasaan terhadap normanorma yang berlaku, dan dalam konteksnya termanifestasikan dalam kebajikankebajikan sosial umum - kesetiaan, kejujuran, kekompakkan dan dependability. (Fukuyama, 2002: 65).

Unsur modal sosial selanjutnya adalah jaringan sosial. Definisi jaringan sebagai unsur modal sosial adalah sekelompok orang yang memiliki norma-norma atau nilai-nilai informal di samping norma-norma atau nilai-nilai yang diperlukan untuk transaksi biasa di pasar (Fukuyama, 2005: 245). Pertukaran informasi yang diwadahi oleh jaringan untuk berinteraksi akhirnya berkontribusi memunculkan kepercayaan di antara mereka (Fukuyama, 2002). Jaringan sosial dapat 


\section{Jurnal Pemikiran Sosiologi Volume 6 No.1 2019 \\ Modal Sosial: Konsep, Inklusivitas dan Pemberdayaan Masyarakat \\ Rusydan Fathy}

terbentuk karena adanya nilai dan norma yang dipegang teguh bersama yang kemudian melandasi lahirnya kerja sama. Namun demikian, kerja sama sosial tidak serta merta muncul begitu saja. Hal tersebut dapat dimunculkan dengan menciptakan identitas bersama, pertukaran moral dan pengulangan interaksi. Fukuyama menjelaskan:

Orang cenderung ceroboh menggunakan istilah asas timbal balik (reciprocity) atau pengorbanan timbal balik (reciprocal altruism). Istilah tersebut dianggap sama dengan istilah tukar-menukar di pasar (market exchange), padahal tidak demikian. Di pasar, barang-barang ditukarkan serentak. Pembeli dan penjual mengikuti perkembangan nilai tukar dengan cermat. Sedangkan menyangkut pengorbanan timbal balik, pertukaran bisa terjadi pada waktu yang berbeda. Pihak yang yang satu memberikan manfaat tanpa mengharapkan balasan langsung, dan tidak mengharapkan imbalan yang sepadan. (Fukuyama, 2005: 212-213).

Dari pemaparan tersebut, terdapat penekanan pada waktu perolehan manfaat atau imbalan yang diterima di kedua belah pihak. Pertukaran pasar terjadi secara serentak dengan memprioritaskan pada perolehan manfaat yang paling tidak setimpal di antara keduanya. Sementara asas timbal balik sama sekali tidak demikian. Prinsip seperti inilah yang merefleksikan kualitas modal sosial yang baik. Terkait dengan pengulangan interaksi, sebagaimana dimaksud oleh Fukuyama:

Orang yang punya reputasi culas akan dihindari, sedangkan orang jujur cenderung mau bekerja sama dengan orang lain yang jujur pula. Karena masa lampau tidak sepenuhnya dapat dipakai sebagai patokan untuk memperkirakan masa depan, selalu ada kemungkinan bahwa orang yang mau bekerja sama hari ini mengkhianati saya esok. Namun kemampuan yang kecil sekalipun untuk membedakan mana orang yang mau bekerja sama dan mana yang tidak tetap dapat memberikan manfaat yang cukup besar pada kemampuan seseorang untuk membangun hubungan kerjasama. (ibid: 209-210).

\begin{tabular}{|c|c|}
\hline Syarat Terbentuknya aringan & Syarat Terbentuknya Kerja Sama \\
\hline $\begin{array}{l}\text { 1. Adanya nilai dan norma } \\
\text { yang dipegang teguh } \\
\text { bersama }\end{array}$ & $\begin{array}{l}\text { 1. Menciptakan identitas bersama } \\
\text { 2. Norma timbal balik (pertukaran moral } \\
\text { antar anggota) }\end{array}$ \\
$\begin{array}{l}\text { 2. Terjalin hubungan yang } \\
\text { bernuansakerja sama }\end{array}$ & \begin{tabular}{l} 
3. Pengulangan interaksi \\
\hline
\end{tabular}
\end{tabular}

Tabel 2: Pembentukan Jaringan dan Kerja Sama Sosial (Sumber: Fathy, 2017: 65)

Sementara itu, bentuk modal sosial berdasarkan tipe ikatan sosial (jaringan sosial) dapat dibedakan sebagai berikut (Woolcock, 2001: 13-14, dalam Usman, 2018: 68):

(a) Modal sosial mengikat (bonding social capital), berarti ikatan antara orang dalam situasi yang sama, seperti keluarga dekat, teman akrab dan rukun tetangga.

(b) Modal sosial menjembatani (bridging social capital), mencakup ikatan yang lebih longgar dari beberap orang, seperti teman jauh dan rekan kerja.

(c) Modal sosial menghubungkan (linking social capital), menjangkau orang-orang pada situasi berbeda yang sepenuhnya berada di luar komunitas, sehingga mendorong anggotanya memanfaatkan banyak sumber daya dari yang tersedia di dalam komunitas. 
Jurnal Pemikiran Sosiologi Volume 6 No.1 2019

Modal Sosial: Konsep, Inklusivitas dan Pemberdayaan Masyarakat

Rusydan Fathy

Modal sosial mengikat cenderung mendorong identitas eksklusif dan mempertahankan homogenitas, sedangkan modal sosial menjembatani cenderung menyatukan dari beragam ranah sosial (Putnam, 2000). Masing masing bentuk tersebut mampu menyatukan kebutuhan yang berbeda dari masing-masing anggota. Modal sosial yang mengikat adalah perekat dan memperkuat identitas spesifik (Putnam, 2000). Modal sosial menjembatani merupakan hubunganhubungan yang menjembatani lebih baik dalam menghubungkan aset eksternal dan bagi persebaran informasi dan dapat membangun identitas dan timbal balik lebih luas (Putnam, 2000). Putnam (2000) dalam Asrori (2014) dijelaskan:

Bridging ditandai oleh hubungan sosial yang bersifat terbuka (inklusif), para anggotanya mempunyai latar belakang yang heterogen. Orientasi kelompok ini lebih ditekankan upaya-upaya bersama dalam mencari jawaban atas permasalahan bersama, serta mempunyai cara pandangan keluar outward looking. Sedangkan bonding yaitu kapital sosial bersifat eksklusif, keanggotannya biasanya didasarkan atas berbagai kesamaan, seperti kesamaan suku, etnis dan agama, hubungan antar individu bersifat tertutup, lebih mengutamakan solidaritas dan kepentingan kelompok. (Asrori, 2014:761).

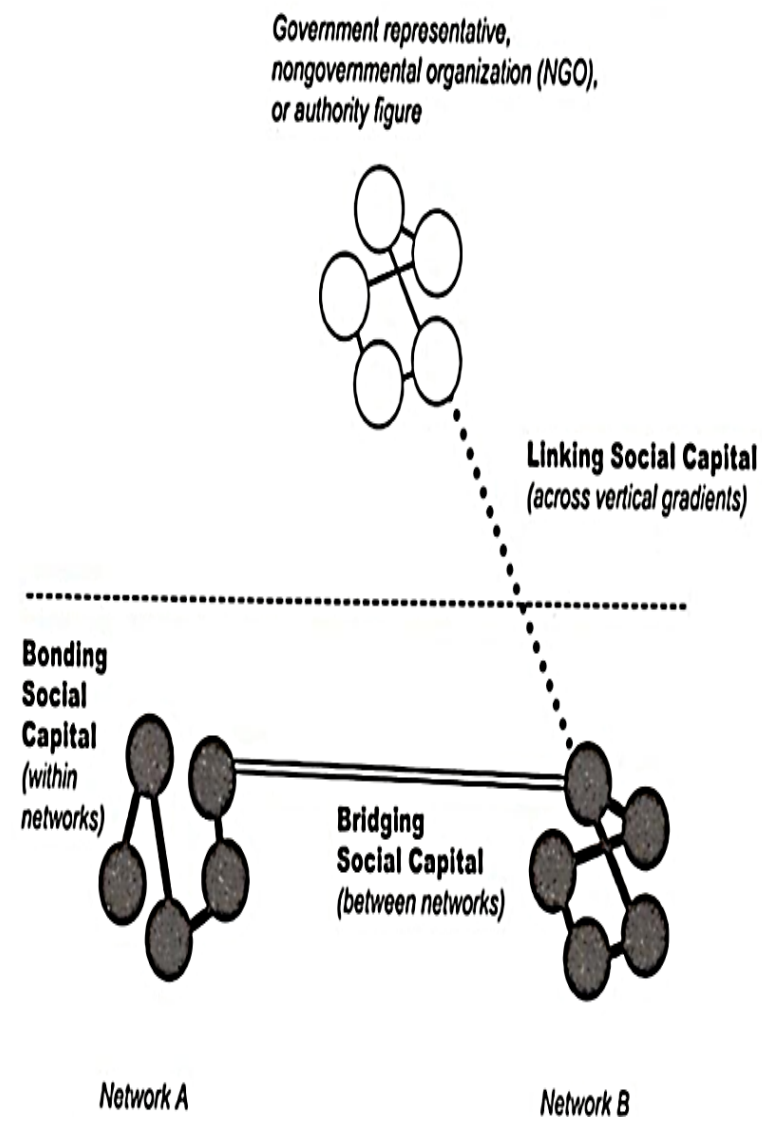

Figur 1. Bonding, Bridging dan Linking Social Capital (Sumber: Babaei, Hamidreza, et.al. 2012)

Dalam pembahasan Putnam, dapat disimpulkan bahwa jaringan dan kerja sama tidak dapat dipisahkan. Bonding social capital berperan dalam menciptakan identitas bersama yang kuat. Hal ini penting sebagai salah satu syarat menumbuhkan kerja sama internal kelompok. Dalam proses pembentukan jaringan, menumbuhkan iklim kerja sama adalah syarat lain selain nilai dan norma bersama (Fukuyama, 2005). Bridging social capital pada gilirannya berperan penting bagi kelompok untuk menciptakan perluasan kerja sama terhadap kelompok lain. Mengembangkan jaringan-jaringan sosial yang 


\section{Jurnal Pemikiran Sosiologi Volume 6 No.1 2019 \\ Modal Sosial: Konsep, Inklusivitas dan Pemberdayaan Masyarakat \\ Rusydan Fathy}

didasarkan pada norma-norma bersama dan iklim kerja sama akan membuat modal sosial berkembang. Jaringan sosial, bagaimanapun memfasilitasi sekumpulan orang yang diikat oleh norma-norma bersama dan saling berhubungan timbal-balik (reciprocity).

Unsur modal sosial yang ketiga adalah kepercayaan. Menurut Fukuyama (2002), kepercayaan adalah efek samping yang sangat penting dari norma-norma sosial yang kooperatif yang memunculkan modal sosial. Kepercayaan adalah sesuatu yang dipertukarkan dengan berlandaskan norma-norma bersama demi kepentingan orang banyak. Kepercayaan menyangkut hubungan timbal balik. Bila masingmasing pihak memiliki pengharapan yang samasama dipenuhi oleh kedua belah pihak, maka tingkat kepercayaan yang tinggi akan terwujud. Tidak dapat dipungkiri jika masyarakat Indonesia belum dikatakan sepenuhnya sejahtera. Kesenjangan dan ketimpangan masih menjadi permasalahan baik di perkotaan maupun perdesaan. Polarisasi yang kian mencolok di masyarakat menandakan bahwa masyarakat Indonesia ada yang tereksklusi secara sosial. Konsep eksklusi sosial sebenarnya tertuju pada melemahnya kapasitas masyarakat. Hal demikian ditandai pula dengan lemahnya tingkat partisipasi, aksesibilitas dan kebebasan masyarakat. Eksklusi sosial merupakan proses (dan juga outcome), individu atau kelompok terpisah dari hubungan sosial yang lebih luas - ditandai dengan tidak berpartisipasi dalam aktifitas masyarakat seperti konsumsi, menabung, produksi, politik dan aktifitas sosial lainnya (Sirovatka dan Meres, 2008).
Modal sosial benar-benar mempengaruhi inklusi sosial, kualitas hidup individu, dan penguatan kapasitas secara personal, pertumbuhan ekonomi, pemerintahan yang demorkatis dan kohesi sosial pada tingkatan makro level (Sirovatka dan Mares, 2008). Menurut Sirovatka dan Mares (2008), keterkaitan antara dimensi modal sosial dengan inklusi sosial adalah sebagai berikut:

\begin{tabular}{|c|c|}
\hline Modal Sosial & Inklusi Sosial(Partisipasi) \\
\hline & $\begin{array}{l}\text { Ekonomi: } \\
\text { - Pasar tenaga kerja (pengangguran atau } \\
\text { tidak) } \\
\text { - Konsumsi (deprivasi material) }\end{array}$ \\
\hline $\begin{array}{l}\text { - Didukung oleh jaringan informal (keluarga, } \\
\text { tetangga dan teman) } \\
\text { - Didukung oleh jaringan formal (asosiasi, } \\
\text { sektor sipil) } \\
\text { - Efek inklusif dari norma bersama dan iklim } \\
\text { kepercayaan }\end{array}$ & $\begin{array}{l}\text { Sosial: } \\
\text { - (tidak) berpartisipasi dalam jaringan } \\
\text { informal } \\
\text { - (tidak) berpartisipasi dalam masyarakat } \\
\text { sipil (jaringan sukarela formal) } \\
\text { - (tidak) memiliki akses ke lembaga } \\
\text { - (tidak)menghargainorma, moral perilaku }\end{array}$ \\
\hline & $\begin{array}{l}\text { Politik/sipil: } \\
\text { - } \quad \text { (tidak) melibatkan proses politik } \\
\text { - } \quad \text { (tidak) masuk dalam keanggotaan partai } \\
\text { politik serta aktifitasnya }\end{array}$ \\
\hline
\end{tabular}

Tabel 3. Dimensi Modal Sosial dan Inklusi/eksklusi Sosial (Sumber: Sirovatka dan Mares, 2008: 535).

Silver (1995) melihat eksklusi sosial dalam tiga sudut pandang: solidaritas; spesialisasi dan monopoli. Paradigma solidaritas melihat melemahnya ikatan sosial antar individu dalam masyarakat. Paradigma spesialisasi melihat bahwa eksklusi sosial adalah konsekuensi dari spesialisasi yang terjadi di masyarakat. Paradigma monopoli melihat eksklusi sebagai akibat dari monopoli kelompok - menyorot dominasi suatu kelompok 


\section{Jurnal Pemikiran Sosiologi Volume 6 No.1 2019 \\ Modal Sosial: Konsep, Inklusivitas dan Pemberdayaan Masyarakat \\ Rusydan Fathy}

terhadap kelompok tertentu. Kondisi melemahnya ikatan sosial sebagaimana dimaksud berarti menandakan melemahnya modal sosial. Dengan melemahnya ikatan sosial, dapat dipastikan bahwa kerja sama sosial akan terhambat. Implikasi dari kerja sama sosial yang terhambat adalah sulit mengembangkan modal sosial. Untuk itulah, diperlukan upaya dalam menumbuhkan lingkungan yang inklusif. Untuk menciptakan lingkungan sosial yang inklusif sangat dibutuhkan modal sosial.

\section{Kajian Modal Sosial}

Dalam konteks pembangunan nasional, telah dilakukan banyak kajian yang melihat peran modal sosial dalam menciptakan tata kelola pemerintahan yang baik, di antaranya yaitu dilakukan oleh Haridison (2013) yang melihat peran modal sosial dalam pembangunan. Hasil kajian tersebut merupakan kajian literatur yang melihat konsep modal sosial yang diterapkan dalam beberapa aspek pembangunan: politik, manusia dan ekonomi. Penelitian tersebut menyimpulkan bahwa permasalahan dan penyimpangan yang terjadi di berbagai negara, determinan utamanya adalah kerdilnya modal sosial yang tumbuh di tengah masyarakat. Sama halnya Haridison, Syahra (2003) menyimpulkan bahwa ketika modal sosial diaplikasikan dengan baik maka kontribusi terpenting pengembangan modal sosial adalah terciptanya kelompok masyarakat yang mandiri dan mampu mewujudkan good governance atau tata kelola pemerintahan yang baik.

Dalam rangka pemberdayaan kepada masyarakat, maka modal sosial masih sangat digemari para akademisi maupun praktisi sebagai kerangka teoritis untuk melahirkan strategi-strategi pemberdayaan. Hasil penelitian Balady (2018) melihat modal sosial dalam pemberdayaan komunitas. Penelitian tersebut menyimpulkan bahwa komunitas masyarakat tertentu memiliki berbagai bentuk modal sosial yang berkontribusi dalam peningkatan kesejahteraan dan kelestarian lingkungan mereka ketika modal sosial tersebut melebur dalam program PLBHK. Lebih jauh, modal sosial di antaranya mampu mengembangkan ekonomi Lembaga Keuangan Mikro (LKM), (Sila, 2010) dan Pedagang Kaki Lima (PKL) (Utomo, 2015). Modal sosial juga hadir sebagai solusi pengentasan kemiskinan Rumah Tangga Miskin (RTM) (Kamarani, 2012). Lebih dari itu, modal sosial juga berguna bagi pemberdayaan ekonomi perempuan (Puspitasari, 2012) dan pemberdayaan komunitas perempuan majelis taklim (Asrori, 2014). Terakhir, penelitian modal sosial yang berhasil ditemukan ternyata berpengaruh bagi perilaku pelaku Usaha Mikro Kecil Menegah (UMKM) (Thobias et al, 2013). Bukan hanya itu, modal sosial ternyata memiliki peran dalam menciptakan ketahanan ekonomi yang baik bagi ojek pangkalan (Fathy, 2017).

Di sisi lain, keterkaitan modal sosial dengan isu lingkungan khususnya masalah persampahan, misalnya dilakukan dalam penelitian Syahli dan Sekarningrum (2017). Hasil penelitian tersebut mendeskripsikan pengelolaan sampah berbasis modal sosial masyarakat. Modal sosial merupakan kekuatan sosial masyarakat dalam mencapai tujuan bersama dalam hal ini menciptakan kawasan bebas sampah. 
Jurnal Pemikiran Sosiologi Volume 6 No.1 2019

Modal Sosial: Konsep, Inklusivitas dan Pemberdayaan Masyarakat

Rusydan Fathy

Modal sosial sebagai sebuah kerangka teoritis seyogianya dapat diadopsi dalam beragam aspek kehidupan masyarakat. Pemanfaatan modal sosial dalam pembangunan, pemberdayaan masyarakat dan pengelolaan lingkungan merupakan contoh bagaimana sebuah modalitas yang bertumpu pada pendayagunaan relasi sosial diaplikasikan. Dapat dibuktikan berdasarkan hasil kajian-kajian terdahulu bahwa setiap masyarakat (dalam arti luas) memiliki potensi modal sosial yang apabila dikembangkan akan memberikan manfaat bagi kemudahan, baik dalam memperoleh keuntungan ekonomi maupun manfaat sosial. Setidaknya ada tiga tema utama dalam kajian mengenai modal sosial yang akan dijabarkan berikut ini.

\section{(1) Kemiskinan dan Eksklusi Sosial}

Kita dihadapkan kepada kemiskinan sebagai masalah yang salah satunya disebabkan justru oleh agenda pembangunan yang kurang inklusif. Kemiskinan merupakan masalah klasik yang sangat kompleks. Kemiskinan merupakan permasalahan yang kompleks, multi dimensional. Oleh karena kompleksitasnya maka kemiskinan berkaitan erat dengan eksklusi sosial. Eksklusi Sosial merupakan konsep yang dipopulerkan oleh Lenoir (1974), berhubungan dengan fenomena marjinalisasi yang terjadi pada kelompok masyarakat dalam kehidupan bangsa Prancis (Syahra, 2010).

Eksklusi sosial merupakan proses (dan juga outcome), individu atau kelompok terpisah dari hubungan sosial yang lebih luas - ditandai dengan tidak berpartisipasi dalam aktifitas masyarakat seperti konsumsi, menabung, produksi, politik dan aktifitas sosial lainnya (Sirovatka dan Meres, 2008). Konsep ekslusi sosial menjadi paradigma baru dalam melihat fenomena kemiskinan dengan lebih komprehensif. Sementara kemiskinan hanya melihat deprivasi ekonomi, maka keunggulan konsep eksklusi sosial adalah melihat deprivasi dari berbagai aspek. Dengan dihadapkan pada kenyataan bahwa kemiskinan itu sendiri adalah multidimensi, maka menggunakan konsep eksklusi sosial menjadi pilihan bijak. Silver (1995) melihat eksklusi sosial dalam tiga sudut pandang: solidaritas; spesialisasi dan monopoli. Paradigma solidaritas melihat melemahnya ikatan sosial antar individu dalam masyarakat. Paradigma spesialisasi melihat bahwa eksklusi sosial adalah konsekuensi dari spesialisasi yang terjadi di masyarakat. Paradigma monopoli melihat eksklusi sebagai akibat dari monopoli kelompok - menyorot dominasi suatu kelompok terhadap kelompok tertentu.

\section{(2) Pembangunan Inklusif Berkelanjutan}

Pembangunan berkelanjutan atau Sustainable Development Goals (SDGs) merupakan agenda global sebagai kelanjutan dari Millenium Development Goals (MDGs). Konsep pembangunan berkelanjutan yang digagas pada pokoknya berisi beberapa tujuan untuk mengubah bumi menjadi tempat yang lebih baik bagi manusia. Beberapa tujuan tersebut tertuang dalam "17 Goals to Transform Our World" yaitu: No Poverty, Zero Hunger, Good health and Well-Being, Quality Education, Gender Equality, Clean Water and Sanitation, Affordable and Clean Energy, Decent Work and Economic Growth, Industry, Innovation and Infrastructure, Reduced Inequalities, Sustainable Cities and Communities. Responsible Consumption and Production, Climate Action, Life Below Water, Life on Land, Peace, Justice and Strong 
Jurnal Pemikiran Sosiologi Volume 6 No.1 2019

Modal Sosial: Konsep, Inklusivitas dan Pemberdayaan Masyarakat

Rusydan Fathy

Institutions and Partnerships for the Goals (http://www.un.org/sustainabledevelopment/).

Dalam tujuan-tujuan pembangunan berkelanjutan tersebut mencerminkan prinsipprinsip inklusivitas misalnya dalam beberapa tujuan berikut: (1) Goal ke-8 yaitu bertujuan meningkatkan pertumbuhan ekonomi yang inklusif dan berkelanjutan, kesempatan kerja yang produktif dan menyeluruh serta pekerjaan yang layak untuk semua; (2) Goal ke-9 yaitu bertujuan membangun infrastuktur yang tangguh, meningkatkan industri inklusif dan berkelanjutan serta mendorong inovasi; (3) Goal ke-10 yaitu bertujuan untuk menjadikan kota dan permukiman inklusif, aman, tangguh dan berkelanjutan; dan (4) Goal ke-16 yaitu bertujuan menguatkan masyarakat yang inklusif dan damai untuk pembangunan berkelanjutan, menyediakan akses keadilan untuk semua dan membangun kelembagaan yang efektif, akuntabel dan inklusif di semua tingkatan.

Berhubungan dengan hal tersebut, Badan Perencanaan dan Pembangunan Nasional, Bappenas (2017) telah menetapkan arah kebijakan dan strategi perkotaan di Indonesia yang diantaranya dinilai mencerminkan prinsip inklusivitas yakni sebagai berikut (Warsilah, 2018): (1) Mewujudkan sistem perkotaan untuk pengurangan kesenjangan; (2) Membangun kota yang aman, nyaman dan layak huni dan terpenuhinya standar pelayanan perkotaan; dan (3) Meningkatkan kapasitas pengelolaan kota yang transparan, akuntabel, partisipatif dan profesional.

Inklusi sosial pada dasarnya menunjukkan keadaan sebuah lingkungan yang mengajak masuk dan mengikutsertakan semua orang tanpa terkecuali sehingga mereka merasa aman dan nyaman dalam melaksanakan hak dan kewajibannya (Warsilah, 2018). Lingkungan yang inklusif menurut Lenoir (1974) dalam Warsilah (2018) adalah lingkungan sosial masyarakat yang terbuka dan menyenangkan serta merangkul semua perbedaan. Inklusivitas kemudian dijadikan sebagai paradigma di dalam pembangunan - pembangunan inklusif, yaitu sebuah pendekatan pembangunan sosial yang secara luas menganalisa suatu proses perbaikan yang berkesinambungan atas suatu masyarakat, atau suatu sistem sosial secara keseluruhan menuju kehidupan yang lebih baik atau lebih manusiawi dengan cara mendukung keberlanjutan umat manusia dan ekologis (Warsilah, 2018).

Pembangunan inklusif sangat condong mendekati kerangka sosial demokratik dan mencakup masalah kesejahteraan dalam kaitannya untuk mengatasi masalah ketimpangan dan kemiskinan (Prasetyantoko, Bahagijo dan Budiantoro, 2012). Pembangunan inklusif mensyaratkan peran aktif masyarakat, baik melalui sistem demorkasi perwakilan maupun demorkasi langsung seperti bentuk-bentuk mekanisme yang partisipatif. Pembangunan inklusif mendukung peran aktif masyarakat sipil dan mengandalkan suara dan reformasi dari bawah (Prasetyantoko, et.al, 2012).

Paradigma pembangunan inklusif memiliki beberapa perbedaan dibandingkan dengan bentuk paradigma pembangunan lainnya seperti dijelaskan dalam tabel berikut: 
Jurnal Pemikiran Sosiologi Volume 6 No.1 2019

Modal Sosial: Konsep, Inklusivitas dan Pemberdayaan Masyarakat

Rusydan Fathy

\begin{tabular}{|l|l|l|l|}
\hline \multicolumn{3}{|l|}{ Perbandingan Paradigma Pembangunan } \\
\hline Aspek & Neoliberal & Sosial-Demokratik & $\begin{array}{l}\text { Pembangunan } \\
\text { Inklusif }\end{array}$ \\
\hline Pertumbuhan & Tujuan & Sarana & Sarana \\
\hline Peran Pasar & Utama & Penting & Penting \\
\hline Peran Negara & Ninimal & Penting & Penting \\
\hline $\begin{array}{l}\text { Strategi Mengatasi } \\
\text { Kemikinan } \\
\text { Ketimpangan }\end{array}$ & Pasif & Aktif & Proaktif \\
\hline Titik Solidaritas & Pasar & Negara & Negaradan Masyarakat \\
\hline
\end{tabular}

Tabel 4: Perbedaan Pembangunan Inklusif dengan Strategi atau Pendekatan Lain (Sumber: Prasetyantoko, et.al, 2012)

\section{(3) Modal Sosial dalam Kebijakan dan Pembangunan}

Berdasarkan kajian literatur terbatas yang disebutkan di atas, jelas bahwa modal sosial adalah aset yang bermanfaat bagi masyarakat. Modal sosial dapat berkolaborasi dengan kebijakan publik - bisa dijadikan sebagai pendekatan atau paradigma dalam merumuskan kebijakan. Dalam International Policy fellowship, Edi Suharto menawarkan strategi kebijakan publik yang dapat dirancang guna mempengaruhi tumbuh-kembangnya modal sosial, yaitu sebagai berikut (http://www.policy.hu. Diakses 3 September 2018):

1. Memperkuat kepercayan sosial melalui: model integrasi dan relasi di dalam dan di luar lembaga pemerintahan. Proses yang mampu mengatasi konflik berdasarkan winwin solution, desentralisasi dalam pengambilan keputusan.

2. Menumbuhkembangkan nilai bersama melalui: kurikulum pendidikan, hukum dan kebijakan keteraturan, identitas bersama sebagai satu bangsa, peraturan yang mempromosikan nilai sosial positif seperti HAM.

3. Mengembangkah kohesifitas dan altruisme melalui: pengurangan pajak bagi perorangan atau perusahaan yang melakukan kegiatan sosial atau tanggung jawab sosial, registrasi dan pengorganisasian kegiatan-kegiatan kedermawanan sosial.

4. Memperluas partisipasi lokal melalui: pendanaan proyek-proyek kemasyarakatan, dukungan bagi program community development, inisiatif-inisiatif yang memperkuat keluarga.

5. Menciptakan jaringan dan kolaborasi melalui: kolaborasi antar lembaga pemerintah dan antar lembaga pemerintah LSM serta lembaga usaha, dukungan terhadap organisasi-organisasi sukarela untuk membangun jaringan dan aliansi.

6. Meningkatkan keterlibatan masyarakat dalam proses atta pemerintahan yang baik, melalui: kampanye agar terlibat dalam pemilihan secara demokratis, konsultasi dan advokasi kebijakan bagi masyarakat, pelibatan masyarakat dalam perumusan kebijakan dan implementasinya, sosialisasi konsep mengenai masyarakat yang aktif, penyediaan sarana informasi pemerintah yang dapat diakses secara luas oleh masyarakat.

Terdapat bukti yang terus berkembang bahwa modal sosial mempunyai pengaruh yang kuat terhadap hasil-hasil pembangunan, termasuk 
Jurnal Pemikiran Sosiologi Volume 6 No.1 2019

Modal Sosial: Konsep, Inklusivitas dan Pemberdayaan Masyarakat

Rusydan Fathy

pertumbuhan, keadilan, dan pengentasan kemiskinan (Grootaert, 1996). Berbagai asosiasi dan institusi menyediakan suatu kerangka kerja informal untuk berbagi informasi (sharing information), mongkoordinasikan aktivitasaktivitas (coordinating activities), dan membuat keputusan-keputusan bersama (making collective decision) (Grootaert, 1996). Terkait hal tersebut, Haridison (2013) menjelaskan:

1. Sharing information: institusi-institusi formal dan informal dapat membantu mencegah kegagalan pasar terkait dengan ketidakcukupan dan ketidaktepatan informasi.

2. Coordinating activities: perilaku yang tidak terkoordinasi atau petualangan yang dilakukan oleh para agen ekonomi, dapat pula menyebabkan kegagalan pasar. Merujuk pada pengalaman proyek-proyek, tampaknya perilaku dimaksud muncul sebagai akibat kurangnya kekuatan institusi sosial baik formal maupun informal dalam rangka mengatur kesepakatan secara adil.

3. Making collective decisions: pembuatan keputusan bersama adalah kondisi yang diperlukan bagi penyediaan barang-barang publik dan pengelolaan eksternalitas pasar.

Tidak berbeda dengan pemerintah, asosiasiasosiasi lokal dan yang bersifat sukarela pun tidak selalu efektif dalam memaksimalkan kemampuan untuk membuat keputusan - keputusan bersama. Dalam konteks ini, asosiasi - asosiasi tersebut tidak semata-mata tergantung dari bagaimana mereka mengatasi persoalan informationsharing, tetapi juga pada derajat keadilan yang tersedia. Institusi - institusi lokal umumnya lebih efektif dalam memperkuat kesepakatan bersama dan tindakan kerja sama bilamana aset-aset didistribusikan secara relatif adil dan keuntungan dapat dibagi secara merata. Dengan demikian pada aras lokal, efisiensi dan keadilan berjalan seiring (Hadison, 2013: 36). Sementara itu, Edi Suharto (2007) menyebutkan beberapa manfaat bagi kebijakan publik yang difokuskan pada pengembangan modal sosial:

Meningkatnya partisipasi masyarakat, menguatnya demokratisasi, menguatnya tindakan kolektif bersama, menguatnya identitas bersama, menurunnya tingkat kejahatan, korupsi dan alienasi, meningkatnya hubungan dan jaringan antar sektor, terjadinya tukar menukar gagasan dan nilai di dalam pluralitas, rendahnya biaya transaksi, menguatnya kemampuan akses masyarakat dalam mengelola sumber daya yang tersedia di sekitar mereka

Studi-studi terdahulu, dalam laporan Syahra (2003) menunjukkan bahwa modal sosial berperan alam setiap aspek pembangunan: politik, ekonomi, manusia dan budaya. Hal ini dikarenakan, modal sosial menekankan pada pentingnya menjaga hubungan baik dan kepercayaan antar sesama.

\section{E. Kesimpulan: Peran Modal Sosial dalam Pemberdayaan Masyarakat}

Mengacu kepada definisi dari Wirutomo (2012), komunitas diartikan sebagai satuan masyarakat yang relatif kecil, memiliki hubungan dan keterikatan yang relatif kuat, dan memiliki kepentingan bersama berdasarkan kesadaran sosial. Selain itu, komunitas memiliki beberapa bentuk yang lebih dikhususkan seperti basis primordial, 
okupasional, spasial dan interest (ketertarikan) (Wirutomo, 2012). Menurut Osborn dan Gaebler (dalam Wirutomo, 2012), komunitas lebih mampu melihat potensi yang dimiliki oleh setiap pribadi anggotanya dibandingkan dengan organisasi profesional yang sering hanya mengedepankan aspek kelemahan saja. Berbagai macam komunitas informal di era modern ini, tidak akan hilang keberadaannya dikarenakan potensi-potensi modal sosial mereka. Sejauh yang diyakini oleh Fukuyama (2002), ketika komunitas-komunitas ini memiliki potensi modal sosial adalah tinggal bagaimana mereka memanfaatkannya dengan cara mereproduksi norma-norma informal bersama, mempererat hubungan ke dalam dan memperluas hubungan ke luar serta menjaga kepercayaan dan melebarkan radius penularannya ke luar komunitas mereka.

Pada gilirannya, modal sosial sangat berperan dalam pemberdayaan masyarakat. Pemberdayaan ditandai dengan kegiatan-kegiatan peningkatan akses pada informasi, partisipasi, penguatan kapasitas organisasi lokal dan serta merta bersifat inklusif (Usman, 2018). Sementara itu, baik di perdesaan maupun perkotaan, bentuk pemberdayaan yang dianggap sesuai ialah pemberdayaan berbasis komunitas (community based empowerment). Dengan kata lain, harus tumbuh kepercayaan antara pemerintah dan masyarakat yang ditandai dengan iklim kerjasama yang baik.

Beberapa prinsip dalam pemberdayaan berbasis komunitas adalah sebagai berikut (Wirutomo, 2012: 34-37):
1. Pembangunan bukan sekedar menghasilkan materi;

2. Pemberdayaan berbasis komunitas artinya menjadikan semua jenis komunitas sebagai unit partisipatif pembangunan locus/tempat pemberdayaan masyarakat;

3. Mencakup semua strata sosial;

4. Mengidentifikasi smeua potensi yang terkandung dalam sebuah komunitas dan siap bermitra dengannya;

5. Tidak diimplementasikan melalui proyekproyek sesaat;

6. Dilakukan melalui penularan atas keberhasilan yang sudah ada di komunitas lain;

7. Diikuti dengan pembagian risorsis (sumberdaya);

8. Harus menuju masyarakat yang inklusif semua harus memperoleh hak dasar meliputi pendidikan, kesehatan, pekerjaan, beribadah, berekreasi dan lain-lain

Semangat modernisasi yang dipenetrasikan ke dalam berbagai aspek kehidupan memang memberikan peningkatan efektifitas dan efisiensi. Namun demikian hal tersebut tidak boleh dipaksakan begitu saja terhadap komunitaskomunitas sebagaimana dimaksud, mengingat keberagaman komunitas dengan keunikannya sendiri. Oleh sebab itu, mengejar pertumbuhan ekonomi dalam pembangunan jangan sampai membunuh potensi komunitas. Namun faktanya, yang terjadi justru adalah eksklusi sosial yang membuat komunitas sebagai kelompok yang termarjinalkan. Padahal, pemberdayaan komunitas tidak boleh diseragamkan polanya, biarkan 
Jurnal Pemikiran Sosiologi Volume 6 No.1 2019

Modal Sosial: Konsep, Inklusivitas dan Pemberdayaan Masyarakat

Rusydan Fathy

komunitas tertentu berkembang dengan potensi dan ciri khas yang dimiliki (Wirutomo, 2012). Oleh karenanya perlu pendekatan pemberdayaan yang tepat dalam rangka mempertahankan identitas komunitas.

Pembangunan dan pemberdayaan masyarakat harus mencakup semua strata sosial (Wirutomo, 2012: 35). Pemberdayaan harus bersifat "community based empowerment" (CBE), sebab pada dasarnya masyarakat beraktifitas dalam berbagai ikatan komunitas seperti kedekatan tempat tinggal, persamaan profesi, agama, suku, hobi ataupun ketertarikan yang masing-masing tumbuh dengan karakteristik berbeda-beda (Wirutomo, 2012: 34). Dengan kata lain, kebijakan yang dihasilkan harus mengakomodasi modal sosial yang dimiliki oleh sebuah komunitas. Dengan menggunakan pendekatan ini, diharapkan pemerintah mampu mengidentifikasi potensi dalam setiap jenis komunitas serta mau bermitra dengan semua kekuatan komunitas (Wirutomo, 2012).

\section{Daftar Pustaka}

\section{Buku:}

Coleman, James, S. 1989. Social Capital in Creation of Human Capital. University of Chicago Press.

Field, John. 2010. Modal Sosial. Terjemahan Nurhadi. Bantul: Kreasi Wacana.

Fukuyama, Francis. 2002. Trust: Kebajikan Sosial dan Penciptaan Kemakmuran. Terj Rusiani. Jogjakarta: Qalam.

2005. Guncangan Besar:Kodrat Manusia dan Tata Sosial Baru. Penerjemah:
Masri Maris. Jakarta: Gramedia Pustaka Utama.

Ritzer, George. (Ed). 2005. Encyclopedia of Social Theory. Vol.II. California: Sage Publication.

Putnam, Robert. 2000. Bowling Alone: The Collapse and Revival of American Community. New York: Simon and Schurster.

Portes, A. 1998. Social Capital: Its Origins and Applications in Modern Sociology. Annual Review of Sociology.

Usman, Sunyoto. 2005. Esai-Esai Sosiologi Perubahan Sosial. Jogjakarta: Pustaka Pelajar.

Wirutomo, Paulus. 2012. Sosiologi Untuk Jakarta: Menuju Pembangunan Sosial Budaya. Jakarta: Lembaga Pemberdayaan Masyarakat Jakarta.

\section{Artikel Jurnal, Skripsi, Tesis Disertasi:}

Achmad, Ridha Vivianti Sam. 2014. "Modal Sosial, Dukungan Sosial dan Ketahanan Sosial Keluarga di Daerah Permukiman Marjinal Kota Bogor". Skripsi. Bogor: Departemen Ilmu Keluarga dan Konsumen Fakultas Ekologi Manusia Institute Pertanian Bogor.

Asrori, Syaifudin. 2014. "Pemberdayaan Perempuan Majlis Taklim Daarunnisa: Analisis Kapital Sosial". Jurnal BIMAS Islam Vol 7(4).

Babaei, Hamidreza, et.al. 2012. "Bonding, Bridging and Linking Social Capital and Empowerment Among Squatter Settlements in Tehran, Iran" World Applied Sciences Journal 1818-4952(17): 119-126. 
Jurnal Pemikiran Sosiologi Volume 6 No.1 2019

Modal Sosial: Konsep, Inklusivitas dan Pemberdayaan Masyarakat

Rusydan Fathy

Balady, Ashfin. 2018. "Aktualisasi Modal Sosial dalam Pemberdayaan Komunitas". Skripsi. Jogjakarta: Fakultas Dakwah dan Komunikasi Universitas Islam Negeri Sunan Kalijaga.

Fathy, Rusydan. 2017. "Modal Sosial dan Ketahanan Ekonomi Ojek Pangkalan Salemba". Skripsi. Jakarta: Universitas Islam Negeri Syarif Hidayatullah.

Haridison, Anyualatha. 2013. "Modal Sosial dalam Pembangunan". JISPAR FISIP Universitas Palangka Raya No 4.

Grootaert, Christian. 1998, "Social Capital: The Missing Link? The World Bank Social Development Family, Enviromentally, and Socially Sustainable Development Network, Social Capital Initiative." Working Paper No. 3.

Kamarani, Neng. 2012. "Analisis Modal Sosial Sebagai Salah Satu Upaya dalam Pengentasan Kemiskinan: Studi Kasus: Rumah Tangga Miskin di Kecamatan Koto Tangah Kota Padang”. Jurnal Manajemen dan Kewirusahawan Vol 3(3): 36-52.

Puspitasari, Dewi Cahyani. 2012. "Modal Sosial Perempuan Dalam Peran Penguatan Ekonomi keluarga”. Jurnal Pemikiran Sosiologi Vol 1(2): 69-80.

Sila, Muhammad Adlin. 2010. "Lembaga Keuangan Mikro dan Pengentasan Kemiskinan: Kasus Lumbung Pitih Nagari di Padang". Jurnal Sosiologi MASYARAKAT Vol 15(1)
Sirovatka Thomas dan Mares Petr. 2008. "Social Exclusion and Forms of Social Capital". Czech Sociological Review Vol 44 (3): 531-555.

Syahli, Rio dan Sekarningrum, Bintarsih. 2017. "Pengelolaan Sampah berbasis Modal Sosial". Sosioglobal: Jurnal Pemikiran dan Penelitian Sosiologi Vol1 (2): 143-151.

Syahra, Rusydi. 2003. "Modal Sosial: Konsep dan Aplikasi". Jurnal Masyarakat dan Budaya, Vol 5 (1): $1-22$

2010. "Eksklusi Sosial: Perspektif Baru Untuk Memahami Devripasi dan Kemiskinan". Jurnal Masyarakat dan Budaya. Edisi Khusus Tahun 2010.

\section{Sumber Lain (Laman Internet):}

Aprillia, Yovita Annisa. Suryaningsih Margareta dan Djumiarti Titik. 2015. "Modal Sosial Masyarakat dalam Pemenuhan Kebutuhan Rumah Layak Huni”. Paper. (https://media.neliti.com/media/publicatio ns/93239-ID-modal-sosial-masyarakatdalam-

pemenuhan.pdf\&ved=2ahUKEwiYpeDfpYbd AhUN148KHdlbBHsQFjABegQICRAB\&usgAOvVaw0YJioJnbPm42h3LerrxWvH\&cshid= 1535134571975) Diakses 3 September 2018)

Suharto, Edi. 2007. "Modal Sosial dan Kebijakan Publik." Paper. (http://www.policy.hu/suharto/Naskah\%2 OPDF/MODAL_SOSIAL_DAN_KEBIJAKAN_SO SIA.pdf) Diakses 3 September 2018). 